\title{
Height-diameter relationships of tropical Atlantic moist forest trees in southeastern
}

\section{Brazil}

Marcos Augusto da Silva Scaranello ${ }^{1, \S}$, Luciana Ferreira Alves ${ }^{2,3}$, Simone Aparecida Vieira ${ }^{1,9}$, Plinio Barbosa de Camargo ${ }^{1 *}$, Carlos Alfredo Joly ${ }^{4}$, Luiz Antônio Martinelli ${ }^{1}$

1USP/ CENA - Lab. de Ecologia Isotópica, C.P. 96 13416-000 - Piracicaba, SP - Brasil.

2University of Colorado/Institute of Arctic and Alpine Research (INSTAAR), PO Box 450 - 80309 - Boulder, CO - USA.

${ }^{3}$ Instituto de Botânica/Núcleo de Pesquisa em Ecologia, C.P. 3005 - 01031-970 - São Paulo, SP - Brasil.

${ }^{4}$ UNICAMP/Instituto de Biologia, C.P. 6109 - 13083-970

- Campinas, SP - Brasil.

*Corresponding author <pcamargo@cena.usp.br>

Edited by: Eros Artur Bohac Francisco / Luís Reynaldo Ferracciú Alleoni

Received June 18, 2010

Accepted September 30, 2011

\begin{abstract}
Site-specific height-diameter models may be used to improve biomass estimates for forest inventories where only diameter at breast height (DBH) measurements are available. In this study, we fit height-diameter models for vegetation types of a tropical Atlantic forest using field measurements of height across plots along an altitudinal gradient. To fit height-diameter models, we sampled trees by DBH class and measured tree height within 13 one-hectare permanent plots established at four altitude classes. To select the best model we tested the performance of 11 height-diameter models using the Akaike Information Criterion (AIC). The Weibull and ChapmanRichards height-diameter models performed better than other models, and regional site-specific models performed better than the general model. In addition, there is a slight variation of heightdiameter relationships across the altitudinal gradient and an extensive difference in the stature between the Atlantic and Amazon forests. The results showed the effect of altitude on tree height estimates and emphasize the need for altitude-specific models that produce more accurate results than a general model that encompasses all altitudes. To improve biomass estimation, the development of regional height-diameter models that estimate tree height using a subset of randomly sampled trees presents an approach to supplement surveys where only diameter has been measured.

Keywords: tree height, elevation
\end{abstract}

\section{Introduction}

The Brazilian Atlantic Forest (hereafter referred to as Atlantic Forest) is a biodiversity hotspot considered as one of the global centers of tree diversity and endemism (Guedes-Bruni et al., 2009) and one of the most threatened tropical forest regions in the world (Myers et al., 2000). Although the Atlantic Forest is one of the most diverse biomes on Earth there is limited information regarding the structure and biomass of this forest (Alves et al., 2010; Vieira et al., 2008).

Tree biomass stocks of tropical forests are traditionally estimated using forest inventory data from sample plots (Brown, 1997) and allometric models that relate tree dry mass to easily measurable variables such as diameter at breast height (DBH) and total height (Chave et al., 2005). These variables, along with wood density (Baker et al., 2004), are applied in general allometric models (Chave et al., 2005) when site-specific models are not available. As there are no available allometric models developed destructively for old-growth Atlantic forest sites (Alves et al., 2010; Vieira et al., 2008), a pantropical allometric model developed by Chave et al. (2005) for tropical moist forests has been suggested to estimate the live tree aboveground biomass (AGB) for the coastal tropical Atlantic

\$Present address: UNICAMP/Instituto de Biologia, C.P. 6109 - 13083-970 Campinas, SP - Brasil.

IPresent address: UNICAMP/Núcleo de Estudos e Pesquisas Ambientais R. dos Flamboyants, 155 - 13083-867 - Campinas, SP - Brasil. forest using $\mathrm{DBH}$, wood density and total height (Alves et al., 2010).

Although useful, the measurement of tree height in tropical forest inventories is time-consuming and expensive. As a consequence, there are few forest models that use tree height as an independent variable (Fang and Bailey, 1998). An alternative to height measurement for all individuals is the application of site-specific heightdiameter models that relate $\mathrm{DBH}$ with measured tree height (Batista et al., 2001). However, height-diameter relationships vary within a geographic region (Peng et al., 2001) due to species composition and local environmental conditions. Hence, there is a growing consensus that the use of site specific height-diameter models fitted using field measures of tree height is an important alternative to reduce uncertainties in forest biomass estimation in tropical forests (Chave et al., 2005; Feldpausch et al., 2010; Nogueira et. al., 2008) and to study forest structure. Therefore, the main objective of this study is to fit and investigate the relation between $\mathrm{DBH}$ and tree height across sites located at different altitudes in the Atlantic Forest of the southeast region of Brazil.

\section{Materials and Methods}

This study was carried out in the São Paulo State Park of Serra do Mar (PESM), southeast Brazil, and near-

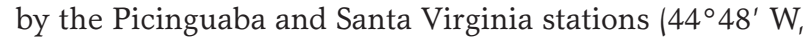
$\left.23^{\circ} 22^{\prime} \mathrm{S}\right)$. The state park contains 47,500 ha of diverse tropical ecosystems, including mangroves, restinga (sandy coastal plain forests), and humid tropical forests from 
sea level up to 1,200 m a.s.l. (SMA, 1998). According to Veloso et al. (1991), the Atlantic Forest, at the latitude of this study, can be subdivided into vegetation types by altitude as follows: lowland forest, submontane forest and montane forest. Along the coastline, there is another Atlantic forest type known as restinga or coastal seasonally flooded forest (Araújo, 1992). Mean annual rainfall in the study area is c. $2600 \mathrm{~mm}$, and monthly average temperature ranges from $17.6^{\circ} \mathrm{C}$ to $24.7^{\circ} \mathrm{C}$ (Sentelhas et al., 1999) varying according to altitude.

From 2006 until 2007, 13 one-hectare permanent plots were established along an altitudinal transect at the Serra do Mar state park to evaluate forest diversity and ecosystem function variation within the north coastal Atlantic Forest of São Paulo state (Alves et al., 2010; Joly et al., 2008). Aiming to represent the range of local environmental conditions, four one-hectare permanent plots $(100 \times 100 \mathrm{~m})$ were established at varying altitudes: in the lowland forest at $100 \mathrm{~m}$ altitude, in the submontane forest at $400 \mathrm{~m}$ altitude and in the montane forest at 1,000 $\mathrm{m}$ altitude. Due to its limited representativeness within the Park relative to the other forest types, only one plot was established at sea level in the restinga forest. All trees $\geq 4.8 \mathrm{~cm} \mathrm{DBH}$ were tagged and mapped to a horizontal distance of $\pm 10 \mathrm{~cm}$ in each permanent plot, and tree circumference was measured within $\pm 1 \mathrm{~mm}$ (Alves et al., 2010). Soils in lowland, submontane and montane forest sites are classified as Inceptisol (USDA taxonomy/ with more than $50 \%$ of sand content and in the restinga forest the soil is classified as Quartzipsamment (USDA taxonomy) with more than $80 \%$ of sand content (Alves et al., 2010). These soils have in common a high sand content, with low $\mathrm{pH}$, low phosphorus concentration, low sum of bases and high aluminum saturation. The density of trees, palms and tree ferns with $\mathrm{DBH} \geq 4.8 \mathrm{~cm}$ ranged from 1467 up to $1885 \mathrm{stems} \mathrm{ha}^{-1}$ (average of 1,626 stems $\mathrm{ha}^{-1}$ ) in the restinga forest, 1,170 up to 1,298 stems $\mathrm{ha}^{-1}$ (average of 1,230 stems $\mathrm{ha}^{-1}$ ) in the lowland forest, 1,517 up to 1,926 stems ha $^{-1}$ (average of 1,727 stems $\mathrm{ha}^{-1}$ ) in the submontane forest and 1,454 up to 1,834 stems $\mathrm{ha}^{-1}$ (average of 1,723 stems ha-1) in the montane forest (Alves et al., 2010). The most rich families in these forests sites are: Myrtaceae, Rubiaceae, Fabaceae, and Lauraceae

Common canopy tree species with $\mathrm{DBH} \geq 30 \mathrm{~cm}$ include: Hieronyma alchorneoides Allemão, Virola bicuhyba (Schott ex Spreng.) Warb, Eriotheca pentaphylla (Vell.) A. Robyns, Sloanea guianensis (Aubl.) Benth, Cryptocaria mandiocanna Meisn., Ecclinusa ramiflora Mart., Licania hoehnei Pilg. and Chrysophyllum viride Mart. \& Eichler ex Miq. For a full description of the sampling design and stand site characteristics, see Alves et al. (2010) and Sousa Neto et al. (2010). Hereafter we will refer to these forest types by the altitudes of occurrence.

Using the database generated by Alves et al. (2010), we randomly selected 268 trees stratified by altitude of occurrence and by $\mathrm{DBH}$ class to perform tree height measurements. The DBH classes were: $<10 \mathrm{~cm}$,
$10-30 \mathrm{~cm}, 30-50 \mathrm{~cm}$ and $\geq 50 \mathrm{~cm}$. We did not include palms in our analysis. Approximately the same number of randomly selected individuals was measured for each diameter class.

Tree height was set as the vertical distance measured from ground to the topmost live leaf. A telescoping measuring rod (Crain Enterprise, model no. 90182) was used to measure the height of trees up to $16 \mathrm{~m}$ height. For trees taller than $16 \mathrm{~m}$ we used a handheld laser range finder (Impulse-200LR, Laser Technology Inc., Englewood, Colorado) that measures distance and calculates height using an angular measurement from a clinometer integrated into the instrument.

There are numerous studies that relate height and diameter for different species and forest regions. In tropical forests, there are few studies reporting height-diameter models and limited information about their performance (Batista et al., 2001; Fang and Bailey, 1998; Feldpausch et al., 2010). Here, we propose a performance test of the eleven linear and non-linear height-diameter models (Table 1), tested earlier by Fang and Bailey (1998) and Batista et al. (2001) in other tropical forests.

The non-linear and linear models were fitted using the functions "Nonlinear Least Squares" and "Fitting linear models" of the R statistical software packages (R Development Core Team, 2011). To assess the performance of height-diameter models and then to test the effect of altitude on estimates, we applied the Akaike Information Criterion (AIC) (Burnham and Anderson, 2002; Chave et

Table 1 - Height-diameter models selected for performance test with data from tropical Atlantic Forest of the São Paulo State Park of Serra do Mar, southeastern Brazil.

\begin{tabular}{|c|c|}
\hline Models & Reference \\
\hline \multicolumn{2}{|l|}{ Linear models } \\
\hline (1) $H=a+b D$ & Batista et al. (2001); Vanclay (1995) \\
\hline (2) $H=a+b \ln D$ & Curtis (1967); Fang and Bailey (1998) \\
\hline \multicolumn{2}{|l|}{ Nonlinear models } \\
\hline \multicolumn{2}{|l|}{ Hyperbolic models } \\
\hline (3) $H=a D /(b+D)$ & Fang and Bailey (1998); Tang (1994) \\
\hline (4) $H=D^{2} /(a+b D)^{2}$ & Fang and Bailey (1998); Huang and Titus (1992) \\
\hline \multicolumn{2}{|l|}{ Power model } \\
\hline (5) $\mathrm{H}=\mathrm{aD}$ & Batista et al. (2001); Fang and Bailey (1998) \\
\hline \multicolumn{2}{|l|}{ Exponential model } \\
\hline (6) $H=e^{a+b / D+1)}$ & Fang and Bailey (1998); Huang and Titus (1992) \\
\hline \multicolumn{2}{|l|}{ Chapman-Richards } \\
\hline \multicolumn{2}{|l|}{ Weibull } \\
\hline \\
\hline $\begin{array}{l}\text { Thonomolecular } \\
\text { (9) } \mathrm{H}=\mathrm{a}\left(1-b \mathrm{e}^{\mathrm{cD}}\right)\end{array}$ & Batista et al. (2001); Fang and Bailey (1998) \\
\hline \multicolumn{2}{|l|}{ Gompertz } \\
\hline $\begin{array}{l}\text { (10) } H=a \exp ^{(-b \exp \mid-C D))} \\
\text { Logistic }\end{array}$ & Batista et al. (2001); Huang and Titus (1992) \\
\hline (11) $H=a /\left(1+b e^{-c D}\right)$ & Batista et al. (2001); Huang and Titus (1992) \\
\hline
\end{tabular}

Note: $\mathrm{H}=$ total tree height $(\mathrm{m}) ; \mathrm{D}=\mathrm{DBH}(\mathrm{cm}) ; \mathrm{a}, \mathrm{b}$ and $\mathrm{c}$ are parameters to be estimated; $e=$ the base of natural logarithm 
al., 2005). The formula of AIC used as the criterion for model selection (Chave et al., 2005) is:

$$
\mathrm{AIC}=-2 \log (\mathrm{L})+2 \mathrm{p}
$$

where $\mathrm{L}$ is the likelihood of the fitted model and $\mathrm{p}$ is the total number of parameters in the model. The best model of the eleven tested models of this database will minimize the AIC value (Burnham and Anderson, 2002). Our analysis was structured as follows: (i) first, we pooled the data (using the subset of 268 trees with measured heights) to select the best model as described above; (ii) second, using the best overall model(s) we fitted the best site-specific height diameter model and calculated the AIC value for each altitude; (iii) finally, we compared the pooled AIC value with the AIC from the sum of the site-specific height-diameter models to test the altitudinal effect (because the data came from the same source; see Burnham and Anderson, 2002). This sum matches the performance of the selected height-diameter model taking into account the site-specific altitude effect, and so can be compared with the pooled model AIC value (Burnham and Anderson, 2002). If the pooled model has a smaller AIC value, there is no altitudinal effect on tree height estimates. The maximum tolerance used to select the best models using the AIC value was equal to Log8 or 2 (Burnham and Anderson, 2002). Although our data apparently show some degree of heteroscedasticity (Figure 1), we decided to acknowledge it and then proceed with our model selection and tests since AIC is not sensitive to the heteroscedasticity (Burnham and Anderson, 2002).

\section{Results and Discussion}

For the pooled data set the non-linear Weibull and Chapman-Richards models performed best (Table 2). All parameters of the best fit models were significant $(p$ $\leq 0.01$, with the exception of the $b$ parameter of the Chapman-Richards model in the $100 \mathrm{~m}$ and $400 \mathrm{~m}$ forests (Table 3). Consequently, we will analyze the heightdiameter relationships variation using only the Weibull height estimates. The height-diameter fits are shown in Figure 1 separated by site/altitude.

Non-linear height-diameter models have biological interpretations and are less sensitive to individual points, making them more stable and more reliable for data extrapolation (Batista et al., 2001). Batista et al. (2001) and Fang and Bailey (1998) also found better performance of non-linear height-diameter models in other tropical forests. The Weibull model has been widely used to describe tree allometric relationships,
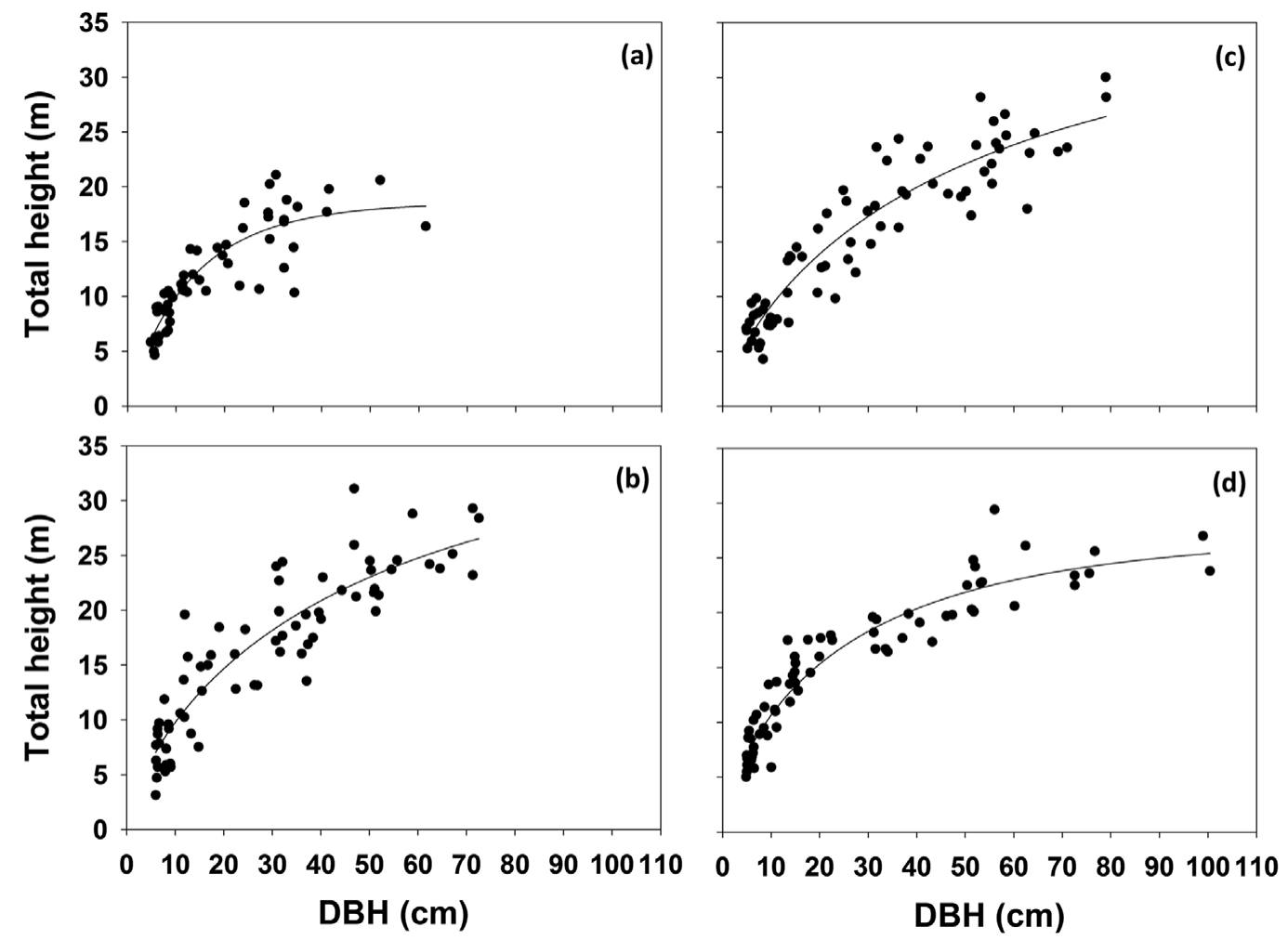

Figure 1 - Weibull fit of tree height-diameter relationships for forests located at sea level (a), $100 \mathrm{~m}$ (b), $400 \mathrm{~m}$ (c) and 1,000 m asl (d). Total height: tree height measured by laser or telescopic rod. Data are from the Atlantic Forest of the São Paulo State Park of Serra do Mar, southeastern Brazil. DBH = diameter at breast height. 
especially for modeling height-diameter relationships (Batista et al., 2001; Fang and Bailey, 1998; Muller-Landau et al., 2006).

The site specific height-diameter Weibull and Chapman-Richards models (AIC from pooled model with the altitude effect in the Table 3) had better performance than the pooled model fit using the full database (AIC from pooled model without the altitude effect in the Table 2). The latter model had the highest AIC value (Table 2 and Table 3), indicating the effect of altitude on tree height estimates and demonstrating the difficulty of extrapolation using a single height-diameter model along the altitudinal gradient. The same result was found by Tasissa et al. (1997) and (Trincado et al., 2007) probably because the

Table 2 - The Akaike Information Criterion (AIC) values for heightdiameter models encompassing all altitudes (pooled model). The best model between the 11 tested models minimizes the AIC value. Data are from the Atlantic Forest of the São Paulo State Park of Serra do Mar, southeastern Brazil. See the corresponding model equation in Table 1.

\begin{tabular}{lc}
\hline Model & AIC \\
\hline Weibull & 1283.2 \\
Chapman-Richards & 1283.5 \\
Monomolecular & 1286.7 \\
Hyperbolic model 3 & 1286.9 \\
Logarithm model & 1287.2 \\
Power model & 1294.0 \\
Gompertz & 1295.0 \\
Logistic & 1303.9 \\
Hyperbolic model 4 & 1305.9 \\
Exponential model & 1323.2 \\
Linear model & 1368.4 \\
\hline
\end{tabular}

use of site-specific equations accounts for local geographic effects in growth patterns of tree communities. This could be especially true along our altitudinal gradient, where slopes are steeper at $400 \mathrm{~m}$ and 1,000 $\mathrm{m}$ than at sea level or at $100 \mathrm{~m}$ altitude (Alves et al., 2010).

The height-diameter relationship was marginally different among forest types up to a $\mathrm{DBH}$ of approximately $30 \mathrm{~cm}$ (Figure 2). Above this $\mathrm{DBH}$ the relationship for the sea level forest was distinct from the other forests. For a given DBH greater than $30 \mathrm{~cm}$, trees at the sea level are shorter than trees at higher altitudes (Figure 2). However, for a constant DBH of $100 \mathrm{~cm}$, tree

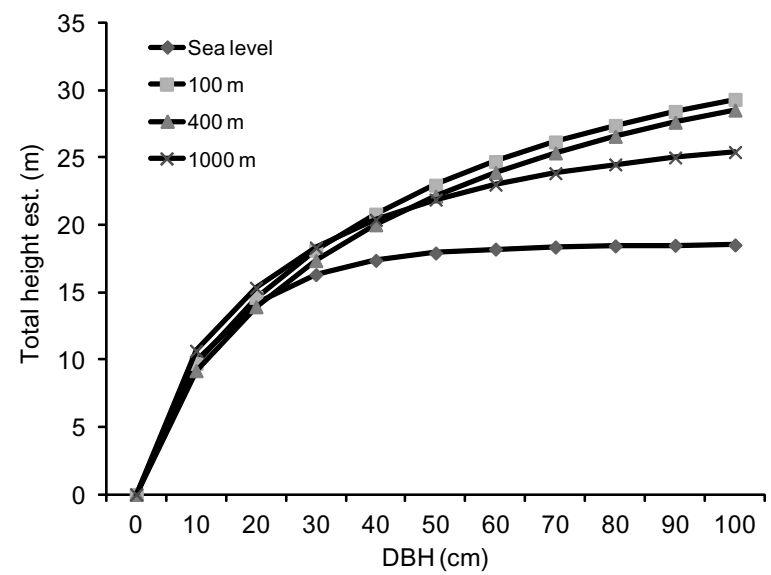

Figure 2 - Tree height estimated by height-diameter Weibull model for forests located at sea level, $100 \mathrm{~m}, 400 \mathrm{~m}$ and 1,000 m asl. Data are from the Atlantic Forest of the São Paulo State Park of Serra do Mar, southeastern Brazil. DBH = diameter at breast height.

Table 3 - Maximum diameter at breast height $(\mathrm{DBH})$ and range of total height measured, parameter values of best fit models and Akaike Information Criterion (AIC) values at sea level, $100 \mathrm{~m}, 400 \mathrm{~m}, 1,000 \mathrm{~m}$ and all forest types (sum of the site specific AIC values). The data are from the Atlantic Forest of the São Paulo State Park of Serra do Mar, southeastern Brazil.

\begin{tabular}{|c|c|c|c|c|c|c|c|c|c|c|}
\hline \multicolumn{11}{|c|}{ Weibull model } \\
\hline \multirow[t]{2}{*}{ Altitude } & \multirow[t]{2}{*}{ N } & \multirow[t]{2}{*}{ DBH max. } & \multirow[t]{2}{*}{$\mathrm{H}$ range } & \multicolumn{6}{|c|}{$\begin{array}{l}\text { Coefficient } \\
\text { Symbol }\end{array}$} & \multirow[t]{2}{*}{ AlC } \\
\hline & & & & $a$ & S.E. & $\mathrm{b}$ & S.E. & $\mathrm{c}$ & S.E. & \\
\hline & & $\mathrm{cm}$ & $\mathrm{m}$ & & & & & & & \\
\hline Sea level & 57 & 61.4 & $4.7-21.8$ & $18.540^{* * *}$ & 1.728 & $0.093^{* * *}$ & 0.026 & $0.919^{* * *}$ & 0.165 & 253.1 \\
\hline $100 \mathrm{~m}$ & 70 & 72.6 & 3.2-31.1 & $36.171^{* *}$ & 13.418 & $0.059^{* * *}$ & 0.012 & $0.725^{* * *}$ & 0.147 & 356.6 \\
\hline $400 \mathrm{~m}$ & 72 & 78.9 & $4.3-30.0$ & $35.528^{* *}$ & 10.902 & $0.055^{* * *}$ & 0.009 & $0.735^{* * *}$ & 0.123 & 354.7 \\
\hline $1,000 \mathrm{~m}$ & 69 & 100.4 & $5.2-29.4$ & $27.188^{* * *}$ & 2.837 & $0.091^{* * *}$ & 0.013 & $0.738^{* * *}$ & 0.093 & 295.3 \\
\hline All forest types & 268 & 100.4 & 3.2-31.1 & $32.304^{* * *}$ & 4.054 & $0.072^{* * *}$ & 0.005 & $0.706^{* * *}$ & 0.059 & 1259.7 \\
\hline \multicolumn{11}{|c|}{ Chapman-Richards model } \\
\hline \multirow{4}{*}{ Altitude } & & & & \multirow{2}{*}{\multicolumn{6}{|c|}{$\begin{array}{l}\text { Coefficient } \\
\text { Symbol }\end{array}$}} & \multirow{3}{*}{ AlC } \\
\hline & $\mathrm{N}$ & DBH max. & $\mathrm{H}$ range & & & & & & & \\
\hline & & & & a & S.E. & $\mathrm{b}$ & S.E. & $\mathrm{c}$ & S.E. & \\
\hline & & $\mathrm{cm}$ & $\mathrm{m}$ & & & & & & & \\
\hline Sea level & 57 & 61.4 & 4.7-21.8 & $18.413^{* * *}$ & 1.450 & $0.069^{*}$ & 0.028 & $0.878^{* * *}$ & 0.247 & 253.2 \\
\hline $100 \mathrm{~m}$ & 70 & 72.6 & 3.2-31.1 & 33.250 *** & 8.476 & 0.017 & 0.013 & $0.662^{* * *}$ & 0.137 & 356.7 \\
\hline $400 \mathrm{~m}$ & 72 & 78.9 & 4.3-30.0 & $32.336^{* * *}$ & 6.574 & 0.017 & 0.010 & $0.682^{* * *}$ & 0.117 & 354.8 \\
\hline $1,000 \mathrm{~m}$ & 69 & 100.4 & $5.2-29.4$ & $25.759^{* * *}$ & 1.531 & $0.031^{* * *}$ & 0.009 & $0.649 * * *$ & 0.086 & 296.1 \\
\hline All forest types & 268 & 100.4 & 3.2-31.1 & $29.981^{* * *}$ & 2.578 & $0.019^{* \star *}$ & 0.006 & $0.633^{* * *}$ & 0.055 & 1260.8 \\
\hline
\end{tabular}

Note: S. E. is the standard error of the coefficient; ${ }^{* * *} p<0.001 ;{ }^{* *} p<0.01 ; \mathrm{N}$, the number of tree samples 
heights decrease with increasing altitude (Figure 2) if the sea level forest is excluded.

At sea level, trees are seasonally flooded during heavy rain events and particularly during the wet season when the soil remains flooded for several weeks (Scarano, 2002). Additionally, soils at the sea level have the highest sand content and the lowest nutrient content among all soils along the altitudinal gradient (Sousa Neto et al., 2011). Possibly, these stress factors contribute to the small stature of trees established in this forest type. With exception to the sea level, large DBH tree heights tend to decline with increasing altitudes (Figure 2). The same trend was found by Lieberman et al. (1996), studying an altitudinal gradient in North of Barva Vulcan, Costa Rica.

What are the possible causes for this variation in height-diameter relationships along the altitudinal gradient? Soils at $100 \mathrm{~m}, 400 \mathrm{~m}$ and $1,000 \mathrm{~m}$ are Inceptisols, with no significant depth difference along the altitudinal gradient (Alves et al., 2010), and with low nutrient content. They are less sandy and have higher nutrient content than soils at sea level (Sousa Neto et al., 2010). More important, there are no differences in soil depth along the altitudinal gradient (Sousa Neto et al., 2010). However, at higher altitudes, air and soil temperatures are lower, with a high incidence of low level clouds and fog formation that reduces annual irradiance (Sousa Neto et al., 2010). These conditions and strong winds are commonly cited as environmental characteristics that distinguish montane from lowland tropical rain forests (Grubb, 1977; Tanner, 1980) and could be the cause of lower tree heights at higher altitudes. Frequently, strong winds cause decrease of tree stature in tropical forests at high altitude (Lawton, 1982). Exposed trees that grow under stress caused by strong winds tend to grow more in diameter than in height, increasing stem strength (Lawton 1982, 1984).

As well as the difference in slope of the terrain is a plausible cause, the local topographic variation among forest types in this altitudinal gradient (see Alves et al., 2010) might be a factor controlling light availability and ultimately, tree height. Montane and submontane forest are located in steeper terrains when compared to the other forest types, so that the vertical distribution of light is expected to be more asymmetric than in flat areas (Alves et al., 2010). As the trees have the crown exposed to more light, they are shorter, reach larger diameters and have also larger crowns (Alves and Santos, 2002).

While we are not able to pinpoint which of these climate conditions is the cause for the observed altitudinal gradient in tree heights we speculate that all of these conditions as well as the difference in the slope of the terrain are plausible causes.

Finally, the tallest statured forest (100 m altitude) was compared with height-diameter models from other studies within the tropical Amazon forest and showed extensive differences in tree stature among these forests (Figure 3). For trees of or above $20 \mathrm{~cm} \mathrm{DBH}$, the tropical Atlantic forest had smaller stature than Amazonian forests in Brazil (Asner et al., 2002; Nogueira et al., 2008). For trees with $100 \mathrm{~cm} \mathrm{DBH}$, this difference reached $76 \%$ when compared with trees in central Amazon. This result supports the need to use tree height as an independent variable in biomass allometric models used to compare different tropical forests, especially in sites where regional site specific biomass models are not available (Chave et al., 2005; Feldpausch et al., 2010; Nogueira et al., 2008). This is especially important in the case of the coastal Atlantic forest of southeastern Brazil due to various limitations resulting in vegetation suppression. Therefore, an alternative solution to the development of biomass allometric equations based on destructive measurements (harvested trees) is the application of general pantropical models including height to estimate live above ground biomass (Vieira et al., 2008).

\section{Conclusions}

The effect of altitude on tree height estimates was evident and emphasize the need for altitude-specific models that produce more accurate results than a general model that encompasses all altitudes. Tree height has a strong influence on the estimate of live aboveground biomass made by allometric models. To improve biomass estimation, the development of regional heightdiameter models that estimate tree height using a subset of randomly sampled trees presents an approach to supplement surveys where only diameters have been measured.

\section{Acknowledgements}

This work was supported by FAPESP, through a master's scholarship provided to M.A.S. Scaranello (proc. $\mathrm{n}^{\circ}$. 07/06821-5) and as part of the Thematic Project Functional Gradient (Process Number 03/12595-7),

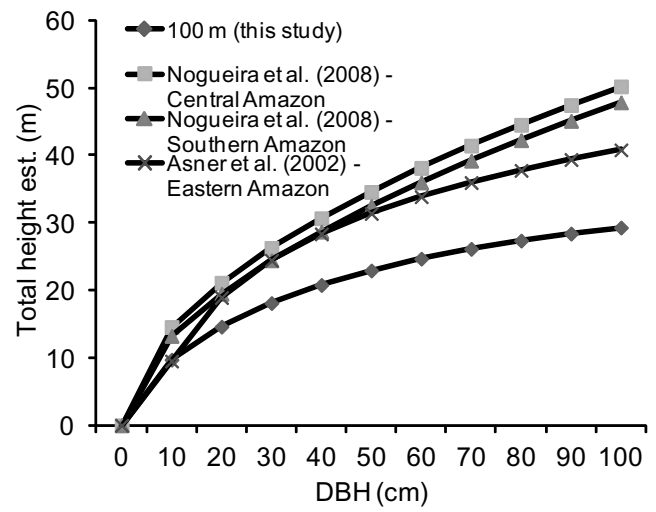

Figure 3 - Tree height estimated by height-diameter Weibull models for a lowland forest at $100 \mathrm{~m}$ asl (this study) and for Central, Southern and Eastern Amazon forest. DBH = diameter at breast height. 
within the BIOTA/FAPESP Program - The Biodiversity Virtual Institute (www.biota.org.br). COTEC/IF 41.065/2005 and IBAMA/CGEN 093/2005 permit. We thank Eliana Simões and João Paulo Villani for their logistic support at Picinguaba and Santa Virgínia field stations. We thank Edmar A. Mazzi for field assistance.
Especially thanks to Michael Keller for the use of the laser range finder for height measurements, and helpful comments in an earlier draft. We also thank João L.F. Batista for helpful comments in an earlier draft. Maria Hunter kindly reviewed the English language in the final version of this manuscript.

Appendix 1 - List of trees stems and species measured along the altitudinal gradient of this study. DBH = diameter at breast height.

\begin{tabular}{|c|c|c|c|c|c|c|c|}
\hline Forest & Altitude & Field code & HT est & DBH & Family & Genus & Species \\
\hline & $\mathrm{m}$ & & & & & & \\
\hline Sea level & 10 & A1282 & 3.5 & 5.6 & Indetermined & - & - \\
\hline Sea level & 10 & A0029 & 14.0 & 32.2 & Euphorbiaceae & Alchornea & triplinervia \\
\hline Sea level & 10 & A0175 & 7.0 & 8.4 & Euphorbiaceae & Alchornea & triplinervia \\
\hline Sea level & 10 & A1099 & 14.0 & 23.8 & Euphorbiaceae & Alchornea & triplinervia \\
\hline Sea level & 10 & A1153 & 17.0 & 13.5 & Euphorbiaceae & Alchornea & triplinervia \\
\hline Sea level & 10 & A1178 & 19.0 & 29.0 & Euphorbiaceae & Alchornea & triplinervia \\
\hline Sea level & 10 & A1330 & 13.0 & 23.1 & Euphorbiaceae & Alchornea & triplinervia \\
\hline Sea level & 10 & A1422 & 12.0 & 32.3 & Euphorbiaceae & Alchornea & triplinervia \\
\hline Sea level & 10 & A1620 & 12.0 & 20.7 & Euphorbiaceae & Alchornea & triplinervia \\
\hline Sea level & 10 & A0913 & 18.0 & 76.9 & Fabaceae & Balisia & pedicellaris \\
\hline Sea level & 10 & A0460 & 15.0 & 52.0 & Clusiaceae & Calophyllum & brasiliensis \\
\hline Sea level & 10 & A0622 & 18.0 & 56.1 & Clusiaceae & Calophyllum & brasiliensis \\
\hline Sea level & 10 & A1382 & 16.0 & 35.0 & Urticaceae & Coussapoa & microcarpa \\
\hline Sea level & 10 & A0806 & 4.0 & 5.8 & Myrtaceae & Eugenia & riedeliana \\
\hline Sea level & 10 & A1015 & 4.0 & 4.8 & Myrtaceae & Eugenia & neolanceolata \\
\hline Sea level & 10 & A1203 & 5.0 & 8.0 & Myrtaceae & Eugenia & riedeliana \\
\hline Sea level & 10 & A1689 & 15.0 & 34.2 & Proteaceae & Euplassa & cantareirae \\
\hline Sea level & 10 & A0314 & 9.0 & 32.2 & Myrtaceae & Gomidesia & schaueriana \\
\hline Sea level & 10 & A0874 & 7.0 & 16.2 & Myrtaceae & Gomidesia & schaueriana \\
\hline Sea level & 10 & A1004 & 13.0 & 61.4 & Myrtaceae & Gomidesia & schaueriana \\
\hline Sea level & 10 & A1077 & 17.0 & 22.9 & Nyctaginaceae & Guapira & opposita \\
\hline Sea level & 10 & A1173 & 14.0 & 12.3 & Annonaceae & Guatteria & gomeziana \\
\hline Sea level & 10 & A1277 & 8.0 & 11.0 & Annonaceae & Guatteria & gomeziana \\
\hline Sea level & 10 & A1247 & 11.0 & 41.1 & Aquifoliaceae & Ilex & integerrima \\
\hline Sea level & 10 & A0569 & 12.0 & 29.3 & Fabaceae & Inga & subnuda \\
\hline Sea level & 10 & A0234 & 4.0 & 5.9 & Bignoniaceae & Jacaranda & puberula \\
\hline Sea level & 10 & A0744 & 6.0 & 11.3 & Bignoniaceae & Jacaranda & puberula \\
\hline Sea level & 10 & A0897 & 11.0 & 27.1 & Bignoniaceae & Jacaranda & puberula \\
\hline Sea level & 10 & A1171 & 14.0 & 34.4 & Bignoniaceae & Jacaranda & puberula \\
\hline Sea level & 10 & A1199 & 12.0 & 8.7 & Bignoniaceae & Jacaranda & puberula \\
\hline Sea level & 10 & A1520 & 9.0 & 18.5 & Bignoniaceae & Jacaranda & puberula \\
\hline Sea level & 10 & A1602 & 12.0 & 32.8 & Bignoniaceae & Jacaranda & puberula \\
\hline Sea level & 10 & A0312 & 5.0 & 8.9 & Clusiaceae & Kielmeyera & petiolaris \\
\hline Sea level & 10 & A0852 & 8.0 & 6.2 & Myrtaceae & Marlierea & tomentosa \\
\hline Sea level & 10 & A1046 & 8.0 & 11.3 & Myrtaceae & Marlierea & obscura \\
\hline Sea level & 10 & A1596 & 6.0 & 6.1 & Myrtaceae & Marlierea & tomentosa \\
\hline Sea level & 10 & A0269 & 6.0 & 8.3 & Celastraceae & Maytenus & litoralis \\
\hline Sea level & 10 & A0784 & 4.0 & 6.5 & Celastraceae & Maytenus & litoralis \\
\hline Sea level & 10 & A1176 & 6.0 & 6.3 & Celastraceae & Maytenus & litoralis \\
\hline Sea level & 10 & A1519 & 7.0 & 7.6 & Celastraceae & Maytenus & litoralis \\
\hline Sea level & 10 & A0183 & 3.0 & 7.6 & Melastomataceae & Miconia & dodecandra \\
\hline Sea level & 10 & A0095 & 10.0 & 11.6 & Myrtaceae & Myrcia & acuminatissima \\
\hline Sea level & 10 & A0870 & 10.0 & 11.8 & Myrtaceae & Myrcia & acuminatissima \\
\hline Sea level & 10 & A0887 & 9.0 & 8.3 & Myrtaceae & Myrcia & acuminatissima \\
\hline Sea level & 10 & A1144 & 10.0 & 8.6 & Myrtaceae & Myrcia & multiflora \\
\hline Sea level & 10 & A1167 & 7.0 & 6.0 & Myrtaceae & Myrcia & acuminatissima \\
\hline
\end{tabular}


Appendix 1 - Continuation.

\begin{tabular}{|c|c|c|c|c|c|c|c|}
\hline Sea level & 10 & A1168 & 13.0 & 14.8 & Myrtaceae & Myrcia & acuminatissima \\
\hline Sea level & 10 & A1368 & 10.0 & 9.3 & Myrtaceae & Myrcia & acuminatissima \\
\hline Sea level & 10 & A0917 & 8.0 & 6.3 & Lauraceae & Nectandra & oppositifolia \\
\hline Sea level & 10 & A1427 & 11.0 & 30.6 & Lauraceae & Nectandra & oppositifolia \\
\hline Sea level & 10 & A1635 & 12.0 & 24.1 & Lauraceae & Nectandra & oppositifolia \\
\hline Sea level & 10 & A0529 & 17.0 & 29.0 & Fabaceae & Ormosia & arborea \\
\hline Sea level & 10 & A0226 & 8.0 & 19.6 & Euphorbiaceae & Pera & glabrata \\
\hline Sea level & 10 & A0259 & 8.0 & 14.3 & Euphorbiaceae & Pera & glabrata \\
\hline Sea level & 10 & A0493 & 10.0 & 13.0 & Euphorbiaceae & Pera & glabrata \\
\hline Sea level & 10 & A0536 & 9.0 & 20.3 & Euphorbiaceae & Pera & glabrata \\
\hline Sea level & 10 & A0562 & 6.0 & 11.3 & Euphorbiaceae & Pera & glabrata \\
\hline Sea level & 10 & A0004 & 12.0 & 41.5 & Fabaceae & Sclerolobium & denudatum \\
\hline Sea level & 10 & A0825 & 5.0 & 5.4 & Fabaceae & Swartzia & simplex var. grandiflora \\
\hline Sea level & 10 & A0465 & 12.0 & 32.2 & Anacardiaceae & Tapirira & guianensis \\
\hline Sea level & 10 & A0955 & 17.0 & 29.3 & Anacardiaceae & Tapirira & guianensis \\
\hline Lowland & 100 & C0056 & 22.0 & 72.6 & Indetermined & - & - \\
\hline Lowland & 100 & C0135 & 18.0 & 58.9 & Indetermined & - & - \\
\hline Lowland & 100 & C0263 & 15.0 & 36.9 & Indetermined & - & - \\
\hline Lowland & 100 & C0292 & 21.0 & 40.0 & Indetermined & - & - \\
\hline Lowland & 100 & C0345 & 18.0 & 64.6 & Indetermined & - & - \\
\hline Lowland & 100 & C0350 & 8.0 & 6.7 & Indetermined & - & - \\
\hline Lowland & 100 & C0403 & 13.0 & 12.6 & Indetermined & - & - \\
\hline Lowland & 100 & C0512 & 20.0 & 44.3 & Indetermined & - & - \\
\hline Lowland & 100 & C0590 & 16.0 & 32.1 & Indetermined & - & - \\
\hline Lowland & 100 & D0885 & 16.0 & 31.6 & Euphorbiaceae & Alchornea & triplinervia \\
\hline Lowland & 100 & E0476 & 7.0 & 6.4 & Euphorbiaceae & Alchornea & triplinervia \\
\hline Lowland & 100 & B0765 & 5.0 & 6.0 & Rubiaceae & Alseis & floribunda \\
\hline Lowland & 100 & E0874 & 6.0 & 6.7 & Myrsinaceae & Ardisia & martiana \\
\hline Lowland & 100 & C0697 & 7.0 & 8.6 & Rubiaceae & Bathysa & mendoncaei \\
\hline Lowland & 100 & E0422 & 4.0 & 14.8 & Rubiaceae & Bathysa & mendoncaei \\
\hline Lowland & 100 & E0840 & 6.0 & 13.3 & Rubiaceae & Bathysa & mendoncaei \\
\hline Lowland & 100 & B0168 & 12.0 & 39.6 & Meliaceae & Cabralea & canjerana \\
\hline Lowland & 100 & D0929 & 16.0 & 38.4 & Myrtaceae & Calyptranthes & lucida \\
\hline Lowland & 100 & B0414 & 13.0 & 15.5 & Sapotaceae & Chrysophyllum & flexuosum \\
\hline Lowland & 100 & D0798 & 6.0 & 11.9 & Sapotaceae & Chrysophyllum & flexuosum \\
\hline Lowland & 100 & C0848 & 8.0 & 7.8 & Chrysobalanaceae & Couepia & venosa \\
\hline Lowland & 100 & B0798 & 5.0 & 6.4 & Rubiaceae & Coussarea & meridionalis var. porophylla \\
\hline Lowland & 100 & E0114 & 6.5 & 9.1 & Rubiaceae & Coussarea & accedens \\
\hline Lowland & 100 & B0241 & 21.0 & 67.1 & Sapindaceae & Cupania & oblongifolia \\
\hline Lowland & 100 & C0841 & 13.0 & 31.4 & Sapindaceae & Cupania & oblongifolia \\
\hline Lowland & 100 & C0703 & 18.0 & 30.8 & Malvaceae & Eriotheca & pentaphylla \\
\hline Lowland & 100 & D0052 & 18.0 & 54.6 & Malvaceae & Eriotheca & pentaphylla \\
\hline Lowland & 100 & B0349 & 9.0 & 22.3 & Myrtaceae & Eugenia & neoaustralis \\
\hline Lowland & 100 & D0731 & 5.5 & 9.0 & Myrtaceae & Eugenia & cf fusca \\
\hline Lowland & 100 & D0739 & 6.5 & 6.0 & Myrtaceae & Eugenia & oblongata \\
\hline Lowland & 100 & B0790 & 12.0 & 46.9 & Moraceae & Ficus & gomelleira \\
\hline Lowland & 100 & D0925 & 16.0 & 46.9 & Moraceae & Ficus & $s p$ \\
\hline Lowland & 100 & B0754 & 5.0 & 8.0 & Nyctaginaceae & Guapira & nitida \\
\hline Lowland & 100 & E0749 & 15.0 & 34.9 & Nyctaginaceae & Guapira & opposita \\
\hline Lowland & 100 & E1200 & 11.0 & 37.1 & Nyctaginaceae & Guapira & opposita \\
\hline Lowland & 100 & B0020 & 15.0 & 62.4 & Phyllanthaceae & Hieronyma & alchorneoides \\
\hline Lowland & 100 & C0712 & 12.0 & 12.0 & Phyllanthaceae & Hieronyma & alchorneoides \\
\hline Lowland & 100 & E0014 & 14.0 & 71.3 & Phyllantaceae & Hieronyma & alchorneoides \\
\hline Lowland & 100 & E0552 & 13.0 & 47.3 & Phyllantaceae & Hieronyma & alchorneoides \\
\hline Lowland & 100 & D0067 & 16.0 & 75.1 & Phyllanthaceae & Hyeronima & alchorneoides \\
\hline
\end{tabular}


Appendix 1 - Continuation.

\begin{tabular}{|c|c|c|c|c|c|c|c|}
\hline Lowland & 100 & C0707 & 9.0 & 15.3 & Euphorbiaceae & Mabea & piriri \\
\hline Lowland & 100 & D1057 & 12.0 & 19.1 & Euphorbiaceae & Mabea & piriri \\
\hline Lowland & 100 & B0811 & 16.0 & 36.1 & Myrtaceae & Marlierea & silvatica \\
\hline Lowland & 100 & D0660 & 8.0 & 22.5 & Myrtaceae & Marlierea & cf obscura \\
\hline Lowland & 100 & E1243 & 16.0 & 50.9 & Celastraceae & Maytenus & sp1 \\
\hline Lowland & 100 & $\mathrm{C} 1005$ & 18.0 & 51.9 & Monimiaceae & Mollinedia & $s p$ \\
\hline Lowland & 100 & D0217 & 9.0 & 8.7 & Monimiaceae & Mollinedia & schottiana \\
\hline Lowland & 100 & D0260 & 6.0 & 6.0 & Monimiaceae & Mollinedia & schottiana \\
\hline Lowland & 100 & D1125 & 14.0 & 30.7 & Monimiaceae & Mollinedia & lamprophylla \\
\hline Lowland & 100 & E0360 & 7.0 & 8.1 & Monimiaceae & Mollinedia & schottiana \\
\hline Lowland & 100 & E0551 & 6.0 & 11.0 & Monimiaceae & Mollinedia & schottiana \\
\hline Lowland & 100 & D0292 & 5.0 & 8.1 & Lauraceae & Ocotea & divaricata \\
\hline Lowland & 100 & E0563 & 7.0 & 16.7 & Lauraceae & Ocotea & velloziana \\
\hline Lowland & 100 & E0686 & 7.0 & 11.7 & Lauraceae & Ocotea & dispersa \\
\hline Lowland & 100 & B0606 & 14.0 & 37.3 & Urticaceae & Pourouma & guianensis \\
\hline Lowland & 100 & B0880 & 13.0 & 26.9 & Sapotaceae & Pouteria & cf. venosa \\
\hline Lowland & 100 & D0258 & 12.0 & 33.4 & Sapotaceae & Pouteria & cf venosa \\
\hline Lowland & 100 & E0527 & 10.0 & 35.4 & Sapotaceae & Pouteria & venosa \\
\hline Lowland & 100 & D0688 & 12.0 & 32.1 & Proteaceae & Roupala & $s p$ \\
\hline Lowland & 100 & E0104 & 4.0 & 6.2 & Rubiaceae & Rudgea & vellerea \\
\hline Lowland & 100 & B0287 & 12.0 & 24.4 & Rubiaceae & Rustia & formosa \\
\hline Lowland & 100 & E0769 & 15.0 & 50.1 & Sapotaceae & Sapotaceae & $s p$ \\
\hline Lowland & 100 & B0461 & 6.0 & 17.4 & Myrtaceae & $s p$ & \\
\hline Lowland & 100 & C0467 & 12.0 & 26.3 & Myrtaceae & $s p$ & \\
\hline Lowland & 100 & B1097 & 8.0 & 30.6 & Combretaceae & Terminalia & januaerensis \\
\hline Lowland & 100 & E0141 & 16.0 & 71.3 & Combretaceae & Terminalia & januarensis \\
\hline Lowland & 100 & B0044 & 7.0 & 6.4 & Olacaceae & Tetrastylidium & grandifolium \\
\hline Lowland & 100 & B0472 & 17.0 & 31.4 & Euphorbiaceae & Tetrorchidium & rubrivenium \\
\hline Lowland & 100 & D0768 & 12.0 & 50.4 & Meliaceae & Trichilia & lepdota \\
\hline Lowland & 100 & B1139 & 16.0 & 51.1 & Myristicaceae & Virola & bicuhyba \\
\hline Lowland & 100 & D0305 & 14.0 & 55.7 & Myristicaceae & Virola & bicuhyba \\
\hline Lowland & 100 & E0689 & 15.0 & 40.4 & Myristicaceae & Virola & bicuhyba \\
\hline Lowland & 100 & E0966 & 14.0 & 51.3 & Myristicaceae & Virola & bicuhyba \\
\hline Submontane & 400 & G1541 & 14.0 & 55.4 & Indetermined & - & - \\
\hline Submontane & 400 & G1718 & 5.8 & 5.0 & Indetermined & - & - \\
\hline Submontane & 400 & G0423 & 5.0 & 5.1 & Rubiaceae & Alseis & floribunda \\
\hline Submontane & 400 & $\mathrm{H} 0304$ & 7.0 & 8.8 & Myrsinaceae & Ardisia & martiana \\
\hline Submontane & 400 & $\mathrm{H} 0021$ & 10.0 & 31.9 & Rubiaceae & Bathysa & australis \\
\hline Submontane & 400 & $\mathrm{H} 1259$ & 8.0 & 13.4 & Rubiaceae & Bathysa & mendoncaei \\
\hline Submontane & 400 & $\mathrm{~J} 0016$ & 7 & 7.0 & Rubiaceae & Bathysa & mendoncaei \\
\hline Submontane & 400 & G0819 & 14.0 & 24.9 & Urticaceae & Cecropia & glaziovii \\
\hline Submontane & 400 & H0615 & 8.0 & 13.4 & Sapotaceae & Chrysophyllum & flexuosum \\
\hline Submontane & 400 & $\mathrm{H} 1368$ & 18.0 & 49.1 & Chrysobalanaceae & Couepia & venosa \\
\hline Submontane & 400 & G0899 & 8.0 & 8.4 & Rubiaceae & Coussarea & accedens \\
\hline Submontane & 400 & H0595 & 9.0 & 16.4 & Rubiaceae & Coussarea & accedens \\
\hline Submontane & 400 & $\mathrm{H} 0617$ & 7.0 & 19.6 & Rubiaceae & Coussarea & accedens \\
\hline Submontane & 400 & $\mathrm{H} 0731$ & 4 & 8.3 & Rubiaceae & Coussarea & meridionalis var. porophyla \\
\hline Submontane & 400 & J0908 & 6 & 11.2 & Rubiaceae & Coussarea & meridionalis var. porophylla \\
\hline Submontane & 400 & G0081 & 20.0 & 33.9 & Lauraceae & Cryptocarya & mandioccana \\
\hline Submontane & 400 & $\mathrm{~J} 0902$ & 17 & 52.3 & Sapotaceae & Ecclinusa & ramiflora \\
\hline Submontane & 400 & $\mathrm{H} 0184$ & 14.0 & 56.3 & Malvaceae & Eriotheca & pentaphylla \\
\hline Submontane & 400 & $\mathrm{H} 0254$ & 16.0 & 50.2 & Malvaceae & Eriotheca & pentaphylla \\
\hline Submontane & 400 & H0556 & 14.0 & 31.4 & Malvaceae & Eriotheca & pentaphylla \\
\hline Submontane & 400 & H0992 & 15.0 & 55.9 & Malvaceae & Eriotheca & pentaphylla \\
\hline Submontane & 400 & $\mathrm{~J} 1588$ & 20 & 54.0 & Malvaceae & Eriotheca & pentaphylla \\
\hline
\end{tabular}


Appendix 1 - Continuation.

\begin{tabular}{|c|c|c|c|c|c|c|c|}
\hline Submontane & 400 & G0606 & 10.0 & 40.5 & Myrtaceae & Eugenia & oblongata \\
\hline Submontane & 400 & J0897 & 10 & 15.2 & Myrtaceae & Eugenia & melanogyna \\
\hline Submontane & 400 & $\mathrm{~J} 1104$ & 15 & 36.3 & Myrtaceae & Eugenia & kleinii \\
\hline Submontane & 400 & H0404 & 13.0 & 46.5 & Rubiaceae & Faramea & pachyantha \\
\hline Submontane & 400 & $\mathrm{~J} 0044$ & 16 & 27.4 & Rubiaceae & Faramea & pachyantha \\
\hline Submontane & 400 & $\mathrm{~J} 1348$ & 13 & 37.8 & Rubiaceae & Faramea & pachyantha \\
\hline Submontane & 400 & G0327 & 12.0 & 34.1 & Nyctaginaceae & Guapira & opposita \\
\hline Submontane & 400 & G1045 & 6.0 & 10.3 & Nyctaginaceae & Guapira & nitida \\
\hline Submontane & 400 & G1305 & 14.0 & 55.5 & Nyctaginaceae & Guapira & opposita \\
\hline Submontane & 400 & H0553 & 14.0 & 29.9 & Nyctaginaceae & Guapira & opposita \\
\hline Submontane & 400 & H0816 & 10.0 & 26.4 & Nyctaginaceae & Guapira & opposita \\
\hline Submontane & 400 & $\mathrm{~J} 1534$ & 15 & 32.6 & Annonaceae & Guatteria & sp.3_J \\
\hline Submontane & 400 & $\mathrm{H} 1215$ & 17.0 & 58.4 & Lecythidaceae & Lecythis & cf. lanceolata \\
\hline Submontane & 400 & H0814 & 6.0 & 6.0 & Chrysobalanaceae & Licania & hoehnei \\
\hline Submontane & 400 & G0227 & 9.0 & 13.9 & Myrtaceae & Marlierea & tomentosa \\
\hline Submontane & 400 & G0884 & 12.0 & 25.9 & Myrtaceae & Marlierea & tomentosa \\
\hline Submontane & 400 & H1558 & 10.0 & 30.6 & Myrtaceae & Marlierea & racemosa \\
\hline Submontane & 400 & $\mathrm{~J} 0675$ & 7 & 5.6 & Melastomataceae & Miconia & $s p$ \\
\hline Submontane & 400 & $\mathrm{H} 1200$ & 14.0 & 19.7 & Sapotaceae & Micropholis & crassipedicellata \\
\hline Submontane & 400 & $\mathrm{H} 0730$ & 6.0 & 7.4 & Monimiaceae & Mollinedia & uleana \\
\hline Submontane & 400 & $\mathrm{~J} 0428$ & 7 & 9.9 & Monimiaceae & Mollinedia & engleriana \\
\hline Submontane & 400 & H0031 & 5.5 & 6.4 & Myrtaceae & Myrcia & pubipetala \\
\hline Submontane & 400 & G0284 & 7.0 & 21.2 & Myrtaceae & Myrciaria & floribunda \\
\hline Submontane & 400 & G0200 & 7.0 & 31.7 & Fabaceae & Myrocarpus & frondosus \\
\hline Submontane & 400 & G0611 & 7.0 & 4.9 & Fabaceae & Myrocarpus & frondosus \\
\hline Submontane & 400 & H0756 & 18.0 & 40.7 & Myrtaceae & Neomitranthes & glomerata \\
\hline Submontane & 400 & G0515 & 11.0 & 36.3 & Lauraceae & Ocotea & dispersa \\
\hline Submontane & 400 & H1516 & 12.0 & 20.4 & Lauraceae & Ocotea & dispersa \\
\hline Submontane & 400 & $\mathrm{~J} 0235$ & 10 & 14.1 & Lauraceae & Ocotea & venulosa \\
\hline Submontane & 400 & G1576 & 12.0 & 43.3 & Sapotaceae & Pouteria & venosa \\
\hline Submontane & 400 & $\mathrm{H} 1140$ & 9.0 & 62.8 & Sapotaceae & Pouteria & psammophila \\
\hline Submontane & 400 & $\mathrm{~J} 0722$ & 17 & 71.0 & Sapotaceae & Pouteria & psammophila \\
\hline Submontane & 400 & $\mathrm{~J} 0654$ & 26 & 18.9 & Burseraceae & Protium & kleinii \\
\hline Submontane & 400 & G0881 & 5.5 & 7.5 & Rubiaceae & Psychotria & nuda \\
\hline Submontane & 400 & H0748 & 11.0 & 21.5 & Myrsinaceae & Rapanea & hermogenesii \\
\hline Submontane & 400 & G0710 & 7.0 & 6.7 & Rubiaceae & Rudgea & jasminoides \\
\hline Submontane & 400 & G0759 & 6.0 & 9.9 & Rubiaceae & Rudgea & jasminoides \\
\hline Submontane & 400 & G0781 & 6.0 & 13.6 & Rubiaceae & Rudgea & jasminoides \\
\hline Submontane & 400 & G0799 & 4.5 & 6.0 & Rubiaceae & Rudgea & jasminoides \\
\hline Submontane & 400 & $\mathrm{H} 0047$ & 4.0 & 7.8 & Rubiaceae & Rudgea & jasminoides \\
\hline Submontane & 400 & H0269 & 6.5 & 9.4 & Rubiaceae & Rudgea & jasminoides \\
\hline Submontane & 400 & H0602 & 7.0 & 31.1 & Rubiaceae & Rudgea & jasminoides \\
\hline Submontane & 400 & $\mathrm{H} 1290$ & 7.0 & 9.4 & Rubiaceae & Rudgea & jasminoides \\
\hline Submontane & 400 & $\mathrm{H} 1435$ & 13.0 & 37.0 & Araliaceae & Schefflera & angustissima \\
\hline Submontane & 400 & G0194 & 9.0 & 69.1 & Elaeocarpaceae & Sloanea & guianensis \\
\hline Submontane & 400 & G0443 & 18.0 & 53.2 & Elaeocarpaceae & Sloanea & guianensis \\
\hline Submontane & 400 & H1019 & 15.0 & 51.2 & Elaeocarpaceae & Sloanea & guianensis \\
\hline Submontane & 400 & $\mathrm{~J} 1843$ & 24 & 58.2 & Elaeocarpaceae & Sloanea & guianensis \\
\hline Submontane & 400 & $\mathrm{~J} 0411$ & 17 & 79.0 & Moraceae & Sorocea & hilarii \\
\hline Submontane & 400 & G0544 & 14.0 & 64.3 & Combretaceae & Terminalia & januarensis \\
\hline Submontane & 400 & G0101 & 25.0 & 42.3 & Combretaceae & Terminalia & januarensis \\
\hline Submontane & 400 & $\mathrm{~J} 0456$ & 14 & 25.5 & Meliaceae & Trichilia & silvatica \\
\hline Submontane & 400 & G0473 & 20.0 & 57.0 & Myristicaceae & Virola & bicuhyba \\
\hline Submontane & 400 & G0552 & 7.0 & 23.2 & Myristicaceae & Virola & bicuhyba \\
\hline Submontane & 400 & $\mathrm{~J} 1326$ & 20 & 78.9 & Myristicaceae & Virola & bicuhyba \\
\hline
\end{tabular}


Appendix 1 - Continuation.

\begin{tabular}{|c|c|c|c|c|c|c|c|}
\hline Submontane & 400 & $\mathrm{~J} 1377$ & 13 & 63.3 & Myristicaceae & Virola & gardneri \\
\hline Montane & 1000 & K0179 & 16.0 & 43.2 & Indetermined & - & - \\
\hline Montane & 1000 & K1263 & 20.0 & 72.6 & Indetermined & - & - \\
\hline Montane & 1000 & L0599 & 9.5 & 9.5 & Indetermined & - & - \\
\hline Montane & 1000 & L0771 & 3.5 & 15.0 & Indetermined & - & - \\
\hline Montane & 1000 & L1025 & 10.5 & 14.5 & Indetermined & - & - \\
\hline Montane & 1000 & K1584 & 8.0 & 9.3 & Indetermined & - & - \\
\hline Montane & 1000 & K0477 & 20.0 & 51.3 & Euphorbiaceae & Alchornea & $s p$ \\
\hline Montane & 1000 & K0870 & 16.0 & 47.3 & Euphorbiaceae & Alchornea & glandulosa \\
\hline Montane & 1000 & K2014 & 30.0 & 62.4 & Meliaceae & Cabralea & canjerana \\
\hline Montane & 1000 & K0375 & 22.0 & 51.7 & Sapotaceae & Chrysophyllum & $s p$ \\
\hline Montane & 1000 & K0572 & 20.0 & 76.7 & Sapotaceae & Chrysophyllum & $s p$ \\
\hline Montane & 1000 & K0710 & 22.0 & 72.5 & Sapotaceae & Chrysophyllum & $s p$ \\
\hline Montane & 1000 & K1140 & 5.5 & 5.0 & Sapotaceae & Chrysophyllum & viride \\
\hline Montane & 1000 & K1255 & 15.0 & 53.2 & Sapotaceae & Chrysophyllum & viride \\
\hline Montane & 1000 & K1636 & 9.0 & 13.9 & Sapotaceae & Chrysophyllum & $s p$ \\
\hline Montane & 1000 & K1843 & 24.0 & 100.4 & Sapotaceae & Chrysophyllum & $s p$ \\
\hline Montane & 1000 & K1646 & 20.0 & 99.0 & Chrysobalanaceae & Couepia & $s p$ \\
\hline Montane & 1000 & K1272 & 11.0 & 52.0 & Lauraceae & Cryptocarya & $s p$ \\
\hline Montane & 1000 & K0353 & 13.0 & 14.9 & Sapindaceae & Cupania & $s p$ \\
\hline Montane & 1000 & K0512 & 8.0 & 6.4 & Proteaceae & Euplassa & $s p$ \\
\hline Montane & 1000 & K1742 & 25.0 & 53.5 & Moraceae & Ficus & $s p$ \\
\hline Montane & 1000 & K1998 & 30.0 & 56.1 & Moraceae & Ficus & $s p$ \\
\hline Montane & 1000 & K0519 & 18.0 & 37.1 & Nyctaginaceae & Guapira & $s p$ \\
\hline Montane & 1000 & K1627 & 12.0 & 18.1 & Nyctaginaceae & Guapira & $s p$ \\
\hline Montane & 1000 & K1814 & 9.0 & 13.9 & Nyctaginaceae & Guapira & $s p$ \\
\hline Montane & 1000 & K0647 & 5.5 & 6.0 & Meliaceae & Guarea & $s p$ \\
\hline Montane & 1000 & K0290 & 14.0 & 20.0 & Chrysobalanaceae & Hirtella & hebeclada \\
\hline Montane & 1000 & K0292 & 8.5 & 11.1 & Chrysobalanaceae & Hirtella & hebeclada \\
\hline Montane & 1000 & K0110 & 20.0 & 34.1 & Chrysobalanaceae & Licania & hoehnei \\
\hline Montane & 1000 & K0524 & 17.0 & 46.1 & Chrysobalanaceae & Licania & hoehnei \\
\hline Montane & 1000 & K0553 & 22.0 & 51.8 & Chrysobalanaceae & Licania & hoehnei \\
\hline Montane & 1000 & K0217 & 9.0 & 10.8 & Monimiaceae & Mollinedia & $s p$ \\
\hline Montane & 1000 & K1586 & 6.5 & 6.3 & Monimiaceae & Mollinedia & $s p$ \\
\hline Montane & 1000 & K1665 & 7.0 & 7.6 & Monimiaceae & Mollinedia & argyrogyna \\
\hline Montane & 1000 & K1987 & 6.0 & 6.5 & Monimiaceae & Mollinedia & schottiana \\
\hline Montane & 1000 & K0729 & 9.5 & 13.3 & Myrtaceae & Myrcia & crocea \\
\hline Montane & 1000 & K1233 & 13.0 & 14.9 & Myrtaceae & Myrcia & crocea \\
\hline Montane & 1000 & K1256 & 13.0 & 31.7 & Araliaceae & Schefflera & $s p$ \\
\hline Montane & 1000 & K1072 & 5.0 & 5.1 & Solanaceae & Solanum & $s p$ \\
\hline Montane & 1000 & K0080 & 5.0 & 5.0 & Lauraceae & $s p$ & \\
\hline Montane & 1000 & K0128 & 24.0 & 33.6 & Myrtaceae & $s p$ & \\
\hline Montane & 1000 & K0199 & 4.5 & 5.1 & Annonaceae & $s p$ & \\
\hline Montane & 1000 & K0303 & 18.0 & 31.5 & Lauraceae & $s p$ & \\
\hline Montane & 1000 & K0330 & 5.0 & 6.0 & Lauraceae & $s p$ & \\
\hline Montane & 1000 & K0452 & 14.0 & 11.1 & Myrtaceae & $s p$ & \\
\hline Montane & 1000 & K0504 & 10.0 & 51.3 & Lauraceae & $s p$ & \\
\hline Montane & 1000 & K0623 & 16.0 & 22.6 & Myrtaceae & $s p$ & \\
\hline Montane & 1000 & K0631 & 6.0 & 10.1 & Rubiaceae & $s p$ & \\
\hline Montane & 1000 & K0638 & 7.0 & 5.7 & Euphorbiaceae & $s p$ & \\
\hline Montane & 1000 & K0674 & 9.5 & 10.9 & Solanaceae & $s p$ & \\
\hline Montane & 1000 & K0725 & 14.0 & 30.9 & Lauraceae & $s p$ & \\
\hline Montane & 1000 & K0807 & 8.0 & 8.7 & Lauraceae & $s p$ & \\
\hline Montane & 1000 & K1083 & 17.0 & 50.4 & Myrtaceae & $s p$ & \\
\hline Montane & 1000 & K1093 & 14.0 & 20.2 & Myrtaceae & $s p$ & \\
\hline
\end{tabular}


Appendix 1 - Continuation.

\begin{tabular}{|c|c|c|c|c|c|c|}
\hline Montane & 1000 & K1210 & 14.0 & 40.6 & Lauraceae & $s p$ \\
\hline Montane & 1000 & K1234 & 7.0 & 5.5 & Lauraceae & $s p$ \\
\hline Montane & 1000 & K1393 & 6.5 & 5.3 & Lauraceae & $s p$ \\
\hline Montane & 1000 & K1452 & 13.0 & 15.6 & Lauraceae & $s p$ \\
\hline Montane & 1000 & K1667 & 16.0 & 17.6 & Myrtaceae & $s p$ \\
\hline Montane & 1000 & K1669 & 28.0 & 75.6 & Lauraceae & $s p$ \\
\hline Montane & 1000 & K1701 & 20.0 & 60.2 & Lauraceae & $s p$ \\
\hline Montane & 1000 & K1787 & 22.0 & 38.3 & Lauraceae & $s p$ \\
\hline Montane & 1000 & K1794 & 7.5 & 7.0 & Myrtaceae & $s p$ \\
\hline Montane & 1000 & K1795 & 6.0 & 4.9 & Myrtaceae & $s p$ \\
\hline Montane & 1000 & K1858 & 15.0 & 31.2 & Lauraceae & $\mathrm{sp}$ \\
\hline Montane & 1000 & K1882 & 15.0 & 22.3 & Myrtaceae & $s p$ \\
\hline Montane & 1000 & K1958 & 15.0 & 13.4 & Myrtaceae & $s p$ \\
\hline Montane & 1000 & K1991 & 7.0 & 8.5 & Myrtaceae & $s p$ \\
\hline Montane & 1000 & L1055 & 6.5 & 6.4 & Myrtaceae & $s p$ \\
\hline
\end{tabular}

\section{References}

Alves, L.F.; Santos, F.A.M. 2002. Tree allometry and crown shape of four tree species in Atlantic rain forest, southeast Brazil. Journal of Tropical Ecology 18: 245-260.

Alves, L.F.; Vieira, S.A.; Scaranello, M.A.; Camargo, P.B.; Santos, F.A.M.; Joly, C.A.; Martinelli, L.A. 2010. Forest structure and live aboveground biomass variation along an elevational gradient of tropical Atlantic moist forest (Brazil). Forest Ecology and Management 260: 679-691.

Araújo, D.S.D. 1992. Vegetation types of sandy coastal plains of tropical Brazil: a first approximation. p. 337-347. In: Seeliger, U., ed. Coastal plant communities of Latin America. Academic Press, New York, NY, USA.

Asner, G.P; Palace, M.; Keller, M.; Pereira, R.; Silva, J.N.M.; Zweede J. 2002. Estimating canopy structure in an Amazon forest from laser range finder and IKONOS satellite observations. Biotropica 34: 483-492.

Bailey, R.L. 1979. The potential of Weibull-type functions as flexible growth curves: Discussion. Canadian Journal of Forest Research 10: 117-118.

Baker, T.R.; Phillips, O.L.; Malhi, Y.; Almeida, S.; Arroyo, L.; Di Fiore, A.; Killeen, T.; Laurance, S.G.; Laurance, W.F.; Lewis, S.L.; Loyd, J.; Monteagudo, A.; Neill, D.A.; Patiño, S.; Pitman, N.C.A.; Silva, N.; Vásquez Martínez, R. 2004. Variation in wood density determines spatial patterns in Amazonian forest biomass. Global Change Biology 10: 545562.

Batista, J.L.; Couto, H.T.Z.; Marquesini, M. 2001. Performance of height-diameter relationship models: analysis in three forest types. Scientia Forestalis 60: 149-163 (in Portuguese, with abstract in English).

Brown, S. 1997. Estimating Biomass and Biomass Change of Tropical Forests: A Primer. FAO, Rome, Italy. (FAO Forestry Paper, 134).

Burnham, K.P.; Anderson, D.R. 2002. Model Selection and Multimodel Inference: A Practical Information-Theoretic Approach. Springer Science, New York, NY, USA.
Chave, J.; Andalo, C.; Brown, S.; Cairns, M.; Chambers, J.C.; Eamus, D.; Fölster, H.; Fromard, F.; Higuchi, N.; Kira, T.; Lescure, J.; Nelson, B.W.; Ogawa, H.; Puig, H.; Riéra, B.; Yamakura, T. 2005. Tree allometry and improved estimation of carbon stocks and balance in tropical forests. Oecologia 145: $87-99$.

Curtis, R.O. 1967. Height-diameter and height-diameter-age equations for second-growth Douglas-fir. Forest Science 13: 365-375.

Fang, Z.; Bailey, R.L. 1998. Height-diameter models for tropical forests on Hainan Island in southern China. Forest Ecology and Management 110: 315-327.

Feldpausch, T.R.; Banin, L.; Phillips, O.L.; Baker, T.R.; Lewis, S.L.; Quesada, C.A.; Affum-Baffoe, K.; Arets, E.J.M.M.; Berry, N.J.; Bird, M.; Brondizio, E.S.; Camargo, P.B.; Chave, J.; Domingues, T.F.; Djagbletey, G.; Drescher, M.; Fearnside, P.M.; França, M.B.; Fyllas, N.M.; Lopez-Gonzalez, G.; Hladik, A.; Higuchi, N.; Hunter, M.H.; Iida, Y.; Abu Silam, K.; Kassim, A.R.; Keller, M.; Kemp, J.; King, D.A.; Lovett, J.C.; Marimon, B.S.; Marimon-Junior, B.H.; Lenza, E.; Marshall, A.R.; Metcalfe, D.J.; Mitchard, E.T.A., Moran, E.F.; Nelson, B.W.; Nilus, R.; Nogueira, E.M.; Palace, M.; Patiño, S.; H. Peh, K.S.; Raventos, M.T.; Reitsma, J.M.; Saiz, G.; Schrodt, F.; Sonké, B.; Taedoumg, H.E.; Tan, S.; White, L.; Wöll, H.; Lloyd, J. 2010. Height-diameter allometry of tropical forest trees. Biogeosciences Discussion 7: 77277793.

Grubb, P.J. 1977. Control of forest growth and distribution on wet tropical mountains: with special reference to mineral nutrition. Annual Review of Ecology and Systematic 8: 83107.

Guedes-Bruni, R.R.; Silva, A.G.; Mantovani, W. 2009. Rare canopy species in communities within the Atlantic Coastal Forest in Rio de Janeiro State, Brazil. Biodiversity Conservation 18: 387-403.

Huang, S.; Titus, S.J. 1992. Comparison of nonlinear height-diameter functions for major Alberta tree species. Canadian Journal of Forest Research 22: 12971304. 
Joly, C.A.; Martinelli, L.A.; Alves, L.F.; Tamashiro, J.Y.; Aidar, M.P.M.; Camargo, P.B.C.; Assis, M.A.; Bernacci, L.C.; Durigan, G. 2008. The permanent plots of "Biota Gradiente Funcional" thematic project: Ombrophylus Dense Forest floristic composition, structure and functioning at the Picinguaba and Santa Virgínia nucleus of the Serra do Mar State Park. p. 109-148. In: Sanqueta, C.R. ed. Monitoring experiences in the Atlantic forest biome using permanente plots, RedeMAP: Rede de Parcelas Permanentes dos Biomas Mata Atlântica e Pampa. Fundação Universidade do Paraná, Curitiba, PR, Brasil (in Portuguese, with abstract in English).

Lawton, R.O. 1982. Wind stress and elfin stature in a montane rain forest tree: an adaptive explanation. American Journal of Botany 69: 1224-1230.

Lawton, R.O. 1984. Ecological constraints on wood density in a tropical montane rain Forest. American Journal of Botany 71: 261-267.

Lieberman, D.; Lieberman, M.; Peralta, R.; Hartshorn, G.S. 1996. Tropical forest structure and composition on a largescale altitudinal gradient in Costa Rica. Journal of Ecology 84: 137-152.

Muller-Landau, H.C.; Condit, R.S.; Harms, K.E.; Marks, C.O.; Thomas, S.C.; Bunyavejchewin, S.; Chuyong, G.; Co, L.; Davies, S.; Foster, R.; Gunatilleke, S.; Gunatilleke, N.; Hart, T.; Hubbell, S.P.; Itoh, A.; Kassim, A.R.; Kenfack, D.; Lafrankie, J.V.; Lagunzad, D.; Lee, H.S.; Losos, E.; Makana, J.R; Ohkubo, T.; Samper, C.; Sukumar, R.; Sun, I.F.; Supardi, M.N.; Tan, S.; Thomas, D.; Thompson, J.; Valencia, R.; Vallejo, M.I.; Villa Muñoz, G.; Yamakura, T.; Zimmerman, J.K; Dattaraja, H.S.; Esufali, S.; Hall, P.; He, F.; Hernandez, C.; Kiratiprayoon, S.; Suresh, H.S; Wills, C.; Ashton, P. 2006. Comparing tropical forest tree size distributions with the predictions of metabolic ecology and equilibrium models. Ecology Letter 9: 589-602.

Myers, N.; Mittermier, R.A.; Mittermeier, C.G.; Fonseca, G.A.B.; Kent J. 2000. Biodiversity hotspots for conservation priorities. Nature 403: 852-858.

Nogueira, E.M.; Nelson, B.W.; Fearnside, P.M.; França, M.B.; Oliveira, A.C.A. 2008. Tree height in Brazil's 'arc of deforestation': shorter trees in south and southwest Amazonia imply lower biomass. Forest Ecology and Management 255: 2963-2972.

Peng, C.; Zhang, L.; Huang, S.; Zhou, X.; Parton, J.; Woods, M. 2001. Developing ecoregion-based height-diameter models for jack pine and black spruce in Ontario. Ministry of Nature Resource, Ontario, CA, USA.
R Development Core Team. 2011. R: A Language and Environment for Statistical Computing. $\mathrm{R}$ Foundation for Statistical Computing, Vienna, Austria.

Scarano, F.R. 2002. Structure, function and floristic relantioships of plants communities in stressful habitats marginal to Brazilian Atlantic rainforest. Annals of Botany 90: 517-524.

Secretaria do Meio Ambiente do Estado de São Paulo [SMA]. 1998. Environmental management plan of Picinguaba nucleus at Serra do Mar State Park, phase 1. SMA, São Paulo, SP, Brazil.

Sentelhas, P.C.; Pereira, A.R.; Marin, F.R.; Angelocci, L.R.; Alfonsi, R.R.; Caramori, P.H.; Swart, S. 1999. Brazil's climatic water balance: water balance of 500 locations in Brazil. Available at: http://www.bdclima.cnpm.embrapa.br/index.php [Accessed Sep. 2, 2009]

Sousa Neto, E.; Carmo, J.B.; Keller, M.; Martins, S.C.; Alves, L.F.; Vieira, S.A.; Piccolo, M.C.; Camargo, P.; Couto, H.T.Z.; Joly, C.A.; Martinelli, L.A. 2010. Soil-atmosphere exchange of nitrous oxide, methane and carbon dioxide in a gradient of elevation in the coastal Brazilian Atlantic forest. Biogeosciences Discussion 7: 5227-5252.

Tang, S. 1994. Self-adjusted height-diameter curves and one entry volume model. Forest Research 7: 512-518.

Tanner, E.V.J. 1980. Studies on the biomass and productivity in a series of montane rain forests in Jamaica. Journal of Ecology 68: $573-588$.

Tasissa, G.; Burkhart, H.E.; Amateis, R.L. 1997. Volume and taper equations for thinned and unthinned loblolly pine trees in cutover, site-prepared plantations. Southern Journal of Applied Forestry 21: 146-152.

Trincado, G.; Vanderschaaf, C.L.; Burkhart, H.E. 2007. Regional mixed-effects height-diameter models for loblolly pine (Pinus taeda L.) plantations. European Journal of Forest Research 126: 253-262.

Vanclay, J.K. 1995. Growth models for tropical forests: a synthesis of models and methods. Forest Science 41: 7-42.

Veloso, H.P.; Rangel, A.L.R.F.; Lima, J.C.A. 1991. Classification of the Brazilian vegetation adapted to an universal system. IBGE, São Paulo, SP, Brazil.

Vieira, S.A.; Alves, L.F.; Aidar, M.P.M.; Araújo, L.S.; Baker, T.; Batista, J.L.F.; Campos, M.C.R.; Camargo, P.B.; Chave, J.; Delitti, W.B.; Higuchi, N.; Honório, E.; Joly, C.A.; Keller, M.; Martinelli, L.A.; De Mattos, E.A.; Metzker, T.; Phillips, O.; Santos, F.A.M.; Shimabukuro, M.T.; Silveira, M.; Trumbore, S.E. 2008. Estimation of biomass and carbon stocks: the case of the Atlantic Forest. Biota Neotropica 8: 21-29. 